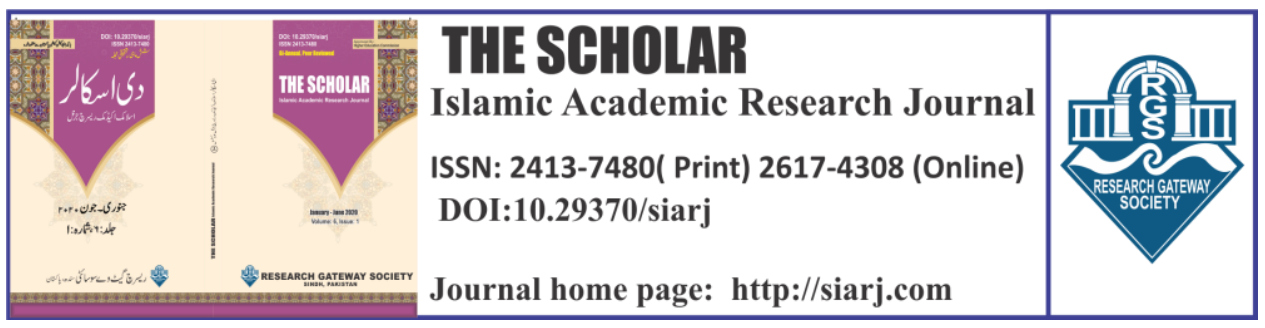

\title{
RULING ON WEARING RED CLOTHING: A COMPREHENSIVE STUDY OF HADITH LITERATURE
}

\author{
Muhammad Nabeel Musharraf \\ Chairman, Australian Islamic Library, Perth, Western Australia \\ Email: chairman@australianislamiclibrary.org \\ ORCID || D: https://orcid.org/0000-0002-9987-5290
}

To cite this article:

Musharraf, Muhammad Nabeel. "RULING ON WEARING RED CLOTHING: A COMPREHENSIVE STUDY OF HADITH LITERATURE." The Scholar-Islamic Academic Research Journal 6, No. 2 (December 28, 2020): 48-85.

To link to this article: https://doi.org/10.29370/siarj/issue11ar3

\begin{tabular}{|c|c|}
\hline Publisher & $\begin{array}{l}\text { The Scholar Islamic Academic Research Journal } \\
\text { Vol. 6, No. } 2 \text { ||July-December } 2020 \text { || P.48-85 } \\
\text { Research Gateway Society }\end{array}$ \\
\hline DOI: & 10.29370/siarj/issue11 ar3 \\
\hline URL: & https://doi.org/10.29370/siarj/ issue11ar3 \\
\hline License: & Copyright c 2017 NC-SA 4.0 \\
\hline Journal homepage & www.siari.com \\
\hline Published online: & $2020-12-28$ \\
\hline
\end{tabular}
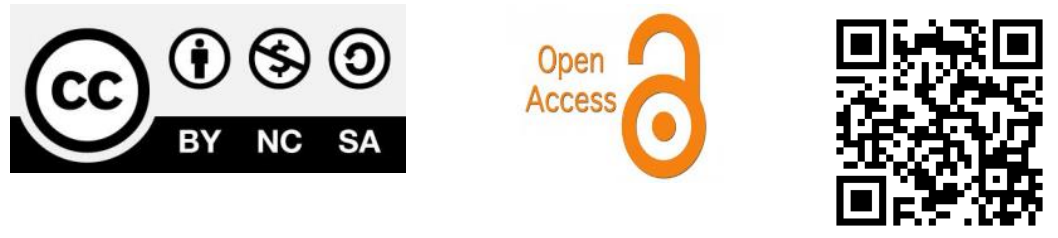
THE SCHOLAR (July- December 2020)

\title{
RULING ON WEARING RED CLOTHING: A COMPREHENSIVE STUDY OF HADITH LITERATURE
}

Muhammad Nabeel Musharraf

\begin{abstract}
:
Islam is a complete code of life that provides guidelines for every walk of human life. All its injunctions and commands contain wisdom and benefits for mankind. While defining the broader framework for various aspects, Islam does provide room for flexibility within the defined margins and limits. This commendable aspect of Islam makes it very easy to follow the religion. However, it is due to excessive use of our own intellect that we make things difficult and complex for us; this often results in the true spirit of Islamic rulings getting lost. Many a time, scholars get lost in the minor details and miss the broader essence behind the rulings. One of such issues that confuse many common people is the ruling regarding permissibility or impermissibility for males to wear the red dress or clothing; several different rulings exist about this matter. In this paper, we have endeavoured to go through the hadith literature and collect all the relevant ahadith that we were able to gather through our extensive review of hadith literature. The collected ahadith have been coded under various themes and analysed holistically. We have also compiled opinions of scholars from various schools of thought and provided possible reasons for their opinions in the light of hadith literature and principles of jurisprudence. Though the paper seems to deal with one specific issue, it can also be used to formulate a research model for studies in hadith literature.
\end{abstract}


KEYWORDS: Clothing, dress, culture, modesty, imitation in religion

\section{INTRODUCTION:}

Modesty is a characteristic built into the nature of human beings and since the time of Adam and Eve (May Allah's peace and blessings be upon them), humans have endeavored to protect their chastity and made use of dresses of various forms ${ }^{1}$. Just like other aspects of human life, civilization, ethics, and behaviors ${ }^{2}$, Islam provides guidelines regarding clothing too. In this regard, it has established certain principles that govern whether a practice is acceptable or not; matters dealing with dressing and clothing are no exception. Islam sets the principles for dressing and clothing that are best for human beings and are aligned to Islam's overall approach towards social system and civilization ${ }^{3}$. In this, Islam has defined the boundaries and everything within those boundaries is accepted; this provides room and flexibility for accommodating diverse cultural practices

\footnotetext{
${ }^{1}$ Sumayyah Meehan, "The Truth behind the Story of Adam and Eve," Khaleej Times, 2008, https://www.khaleejtimes.com/editorialscolumns/the-truth-behind-the-story-of-adam-and-eve.

2 Sayyed Abul A'la Maududi, Fundamentals of Islam: Let Us Be Muslim (Ahsan Publication, 1985).

${ }^{3}$ Dr. Israr Ahmed, "Islam ka Samaji aur Muasharti Nizam@, Peace TV, 2004; Retrieved from: https://quranacademy.com/SnapshotView/MediaID/5166/Title/23-IslamKa-Samaji-Aur-Muasharti-Nizam_-India-Tour-2004
} 
of Muslims from around the world ${ }^{4}$. Accordingly, it is very important for Muslims to thoroughly check the conformance of their practices against the relevant guidelines from the Quran and Sunnah. The current paper is an attempt in this regard concerning the topic at hand - permissibility or impermissibility for men to wear red clothing. The opinions of scholars on this topic vary ${ }^{5}$; the topic, therefore, requires a deeper investigation in the light of the Quran and Sunnah.

Nowadays red clothing and dresses, though in various shades from very light to very dark, have become very common among males as well as females. There are various opinions found among the scholars regarding the permissibility or impermissibility of wearing such dresses for which they present various reasons or adillah (proofs). However, considering significant differences in the fatawa of scholars on this matter, there is a need to put all the pieces of evidence together and analyze them holistically in order to derive a well-informed and well-researched fresh ruling on this matter considering the present times, or to pick an existing

${ }^{4}$ Tesneem Alkiek, "The Flexibility of Islamic Law" (2018 Yaqeen/MAS Academic Conference, USA: Yaqeen Institute for Islamic Research, 2018), https://yaqeeninstitute.org/[[...slugs]].

DEANA NASSAR, "Islam Is Simple, Don't Make It Complicated," Arab News, April 2, 2015, https://www.arabnews.com/islamperspective/news/726926.

${ }^{5}$ Khalid Saifullah Rahmani, "Preferred and Disapproved Colors for Clothing" (Ilm Gate, March 9, 2015), http://www.ilmgate.org/fiqh-ofclothing-color/. 
opinion that is most closely aligned with the guidelines from the sunnah. This has to be done while keeping in mind the principles of usool al-fiqh and other circumstantial factors linked to the related ahadith. The current paper has been written to accomplish this objective.

\section{SCOPE AND APPROACH OF THE CURRENT PAPER}

The Quran provides broader instructions and principles mainly; no direct commands or prohibitions are found in it in relation to our topic of research. The intent of this paper, therefore, is to analyze the body of hadith literature in relation to our topic of research: permissibility or impermissibility of wearing red dresses according to the Quran and Sunnah. We have therefore focussed mainly on the hadith books during the literature and analysis. In doing so, we have searched through key books of hadith (including the 8 most commonly referred collections comprising of As-Sihah As-Sitta, Musnad Ahmed and Muwatta Imam Malik) and gathered all the relevant ahadith from them that we came across. As Dr. Jonathan Brown highlights, the individual ahadith are pieces of data that are required to be looked at holistically before making any conclusions. We have coded the collected ahadith under various themes and then analyzed them to derive the ruling ${ }^{6}$.

${ }^{6}$ Jonathan A. C. Brown, Hadith: Muhammad's Legacy in the Medieval and Modern World (Oneworld Publications, 2009). 
3. Literature Review: Ahadith that indicate permissibility to own or wear red clothing:

\subsection{AHADITH ABOUT THE RED CLOTH IN THE GRAVE OF THE MESSENGER} OF ALLAH SWT:

Hadith 01: Ibn Abbas narrated: "A red velvet cloth was placed in the grave of the Prophet."

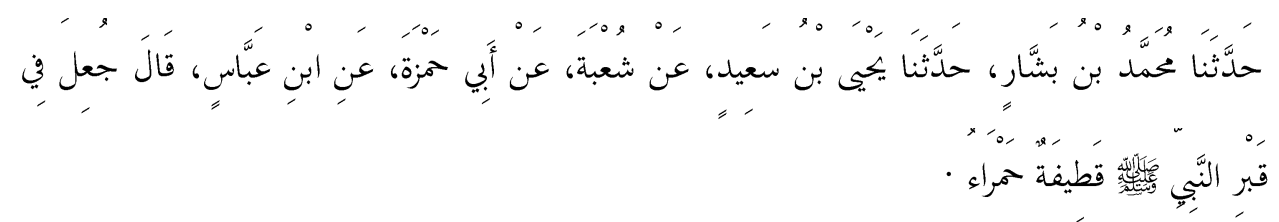

(Jami`at-Tirmidhi 1047 - Saheeh)

Other ahadith that convey the same or similar meaning and message:

- Hadith 02: Sahih Muslim 967

- Hadith 03: Jami` at-Tirmidhi 1047

- Hadith 04: Sunan Nasai 2012

- Hadith 05: Sunan Ibn Majah 1628

It is to be noted about this hadith that the act of placing of the red velvet was done by a freed slave, Shuqran ${ }^{7}$, as the above ahadith elaborate, who placed this sheet in order to prevent the use of this red velvet sheet of the Prophet by anyone else. Some commentaries suggest that Abdullah Ibn

\footnotetext{
${ }^{7}$ Mahajjah Institute, "Shuqran al Habashi” (Mahajjah Institute, 2020), https://mahajjah.com/shuqran-al-habashi/.
} 
Ruling on Wearing Red Clothing: a Comprehensive Study of Hadith Literature

Abbas R.A. disliked placing such a thing in the grave and it might have been taken out. In any case, it indicates that the Prophet cloth.

\subsection{AHADITH THAT SHOW THAT THE COMPANIONS WORE RED DRESS:}

Hadith 06: It was narrated from Ibn Buraidah that his father said: "While the Messenger of Allah (箘) was on the minbar, Al-Hasan and Al-Husain came wearing red shirts, walking and stumbling. He came down and picked them up, then said: 'Allah has spoken the truth: Your wealth and your children are only a trial.' I saw these two walking and stumbling in their shirts, and I could not be patient until I went down and picked them up."'

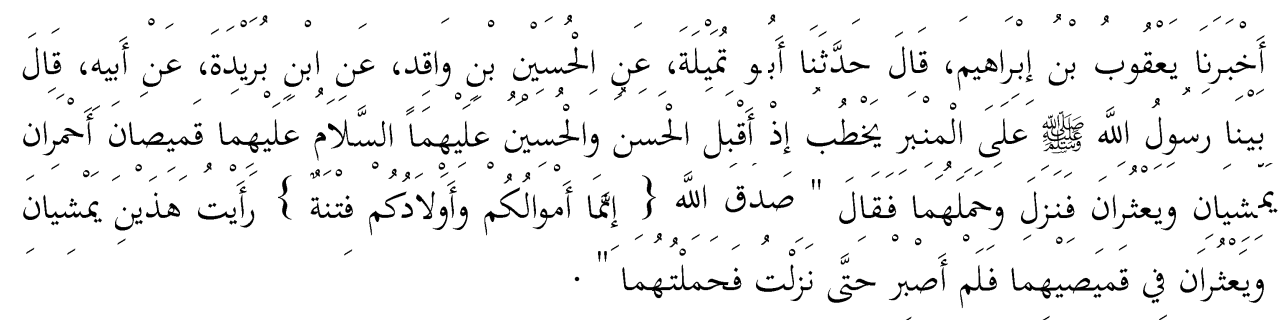

(Sunan an-Nasa'i 1585 - Saheeh)

Other ahadith that convey the same or similar meaning and message:

- Hadith 07: Sunan Abu Dawud 1109

- Hadith 08: Sunan Nasai Book 14 hadith 1424

- Hadith 09: Jami Tirmidhi, book 49 hadith 4143

- Hadith 10: Sunan Ibn Majah 32 Hadith 3731

The above ahadith do not describe whether the clothing contained stripes of any other design or not. They have been defined only as red. This 
Ruling on Wearing Red Clothing: a Comprehensive Study of Hadith Literature

indicates that there is no objection in children to wear red.

Hadith 11: Sulaiman bin Abdullah says I saw those Sahaba who were from the Al-Muhajireen Al-Awwaleen (those Sahaba who were among the first to migrate to Medina - i.e. that was an indication of their status and rank) wearing turbans of cotton material. The colors were black, white, green, red, and yellow. Some would tie it in such a fashion that they would first place one end of the turban on their heads, then the cap, and then continue tying the turban on the fold of the cap. They would not wrap it from under the chin.

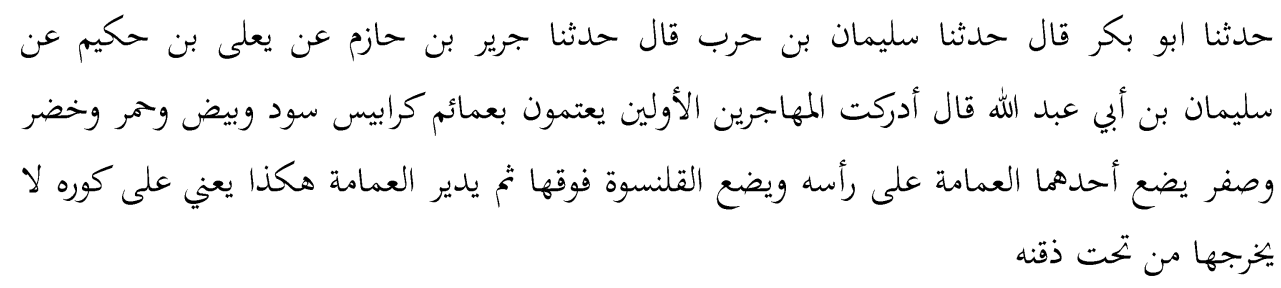

(Musannaf Ibn Abi Shayba - 24987)

The above hadith indicates that the sahaba found nothing wrong with wearing red turbans. According to some narrations, the Prophet 齔is reported to have done wiping over his head during the wudhu under his Qitri Umamah or turban. Scholars explain that this type of cloth also contains a red color in it ${ }^{8}$.

Hadith 12: Narrated Muhammad R.A., we were with Abu Huraira while he was wearing two linen garments dyed with red clay. He cleaned his

الاستذكار الجامع لمذاهب فقهاء الأمصار وعلماء الأقطاء فيما تضمنه الموطأ 8 - من (IslamKotob, n.d.), 34. 
Ruling on Wearing Red Clothing: a Comprehensive Study of Hadith Literature

nose with his garment, saying, "What a time! What a time! Abu Huraira is cleaning his nose with linen! There was a time when I would fall senseless between the pulpit of Allah's Messenger (4) and 'Aisha's dwelling whereupon a passerby would come and put his foot on my neck, considering me a mad man, but in fact, I had no madness, I suffered nothing but hunger."

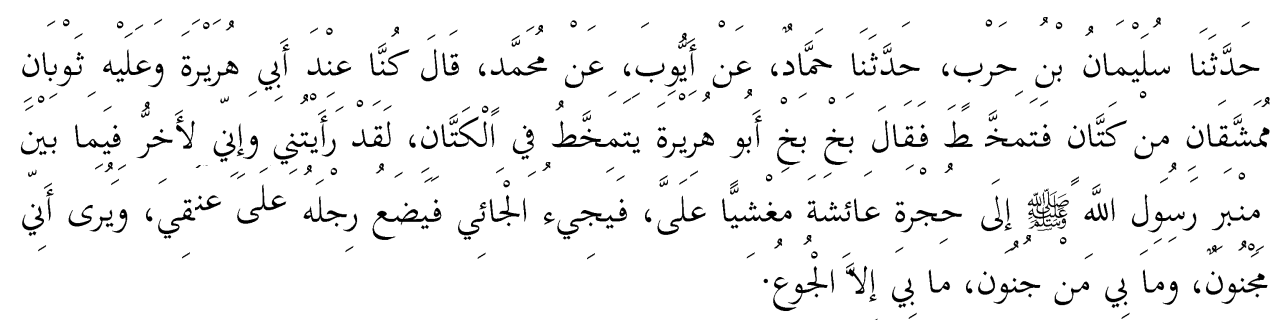

(Sahih al-Bukhari 7324)

Other ahadith that convey the same or similar meaning and message:

- Jami Tirmidhi 2367

- Shamail Muhammaddiyah 368

Hadith 13: Yahya related to me from Malik, from Abdullah ibn Abi Bakr, that Abd ar-Rahman ibn Amir ibn Rabia said, "I once saw Uthman ibn Affan in ihram on a hot summer's day at al-Arj; he had covered his face with a red woolen cloth. Some game-meat was brought to him and he told his companions to eat. They said, 'Will you not eat then?', and he said, 'I am not in the same position as you. It was hunted for my sake.' "

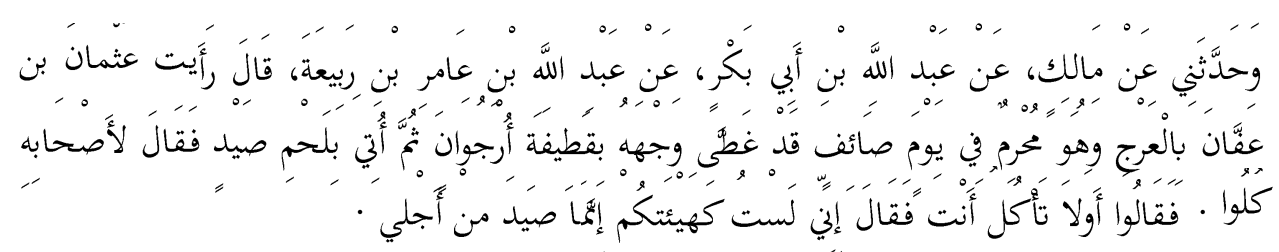


Ruling on Wearing Red Clothing: a Comprehensive Study of Hadith Literature

(Al-Muwatta Imam Malik, Book 20, Hadith 789)

From the above ahadith, it is apparent that the companions used red in their clothing in various forms including the face cover, head cover, suits, and so on.

\subsection{WEARING RED DRESSES INSIDE THE HOUSES}

Hadith 14: Yahya related to me from Malik from Nafi that Abdullah ibn Umar wore garments dyed with red earth and dyed with saffron.

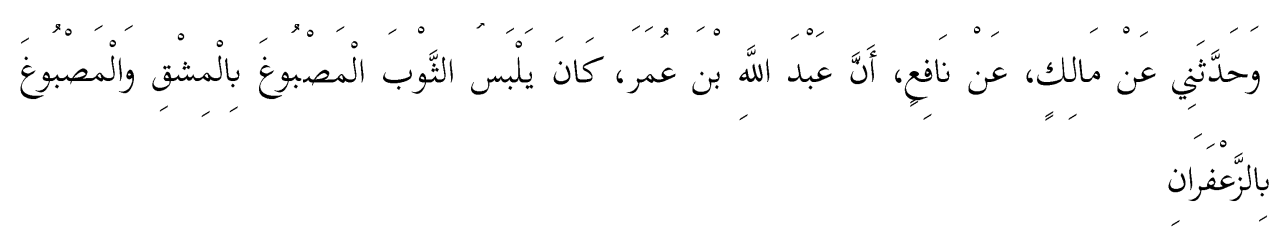

(Muwatta Imam Malik, Book of Dress, Hadith 4)

Hadith 15: Musa ibn Dihqan said, "I saw Ibn 'Umar sitting on a wedding seat, wearing a red garment." 'Imran ibn Muslim said, "I saw Anas sitting on a bed, placing one foot over another."

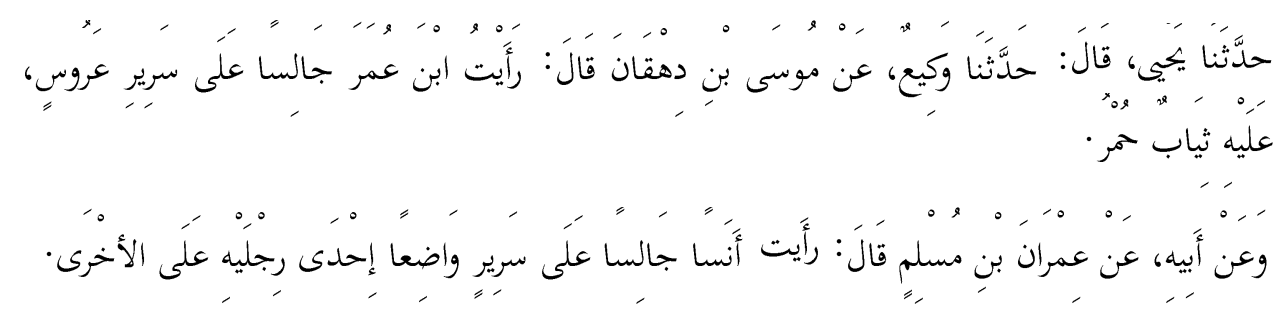

(Al-Adab Al-Mufrad 1165 - Daif)

Imam Malik:

"I disapprove of youths wearing any gold because I heard that the Messenger of Allah , may Allah bless him and grant him peace, forbade 
Ruling on Wearing Red Clothing: a Comprehensive Study of Hadith Literature

wearing gold rings, and I disapprove of it for males old or young." Yahya said, "I heard Malik say about men wearing wraps dyed with safflower in their houses and courtyards, 'I do not know that any of that is haram but I prefer other garments than that."'

From the above, it is apparent that according to Imam Malik, the matter of wearing red inside the houses was a matter that was not haram, though he preferred other colors over it.

Hadith 16: Abdullah, the freed slave of Asma' (the daughter of Abu Bakr). the maternal uncle of the son of 'Ata, reported: Asma' sent me to 'Abdullah b. 'Umar saying: The news has reached me that you prohibit the use of three things: the striped robe, saddle cloth made of red silk, and the fasting in the holy month of Rajab. 'Abdullah said to me: So far as what you say about fasting in the month of Rajab, how about one who observes continuous fasting? -and so far as what you say about the striped garment, I heard Umar b. Khattab say that he had heard from Allah's Messenger (籍): He who wears silk garment has no share for him (in the Hereafter), and I am afraid it may not be that striped garment; and so far as the red saddlecloth is concerned that is the saddle cloth of Abdullah and it is red. I went back to Asma' and informed her whereupon she said: Here is the

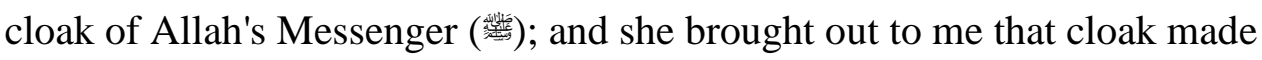
of Persian cloth with a hem of brocade, and its sleeves bordered with brocade and said: This was Allah's Messenger's cloak with 'A'isha until she died, and when she died, I got possession of it. The Apostle of Allah (籍) used to wear that, and we washed it for the sick and sought cure thereby (i.e. through the water of the washing). 


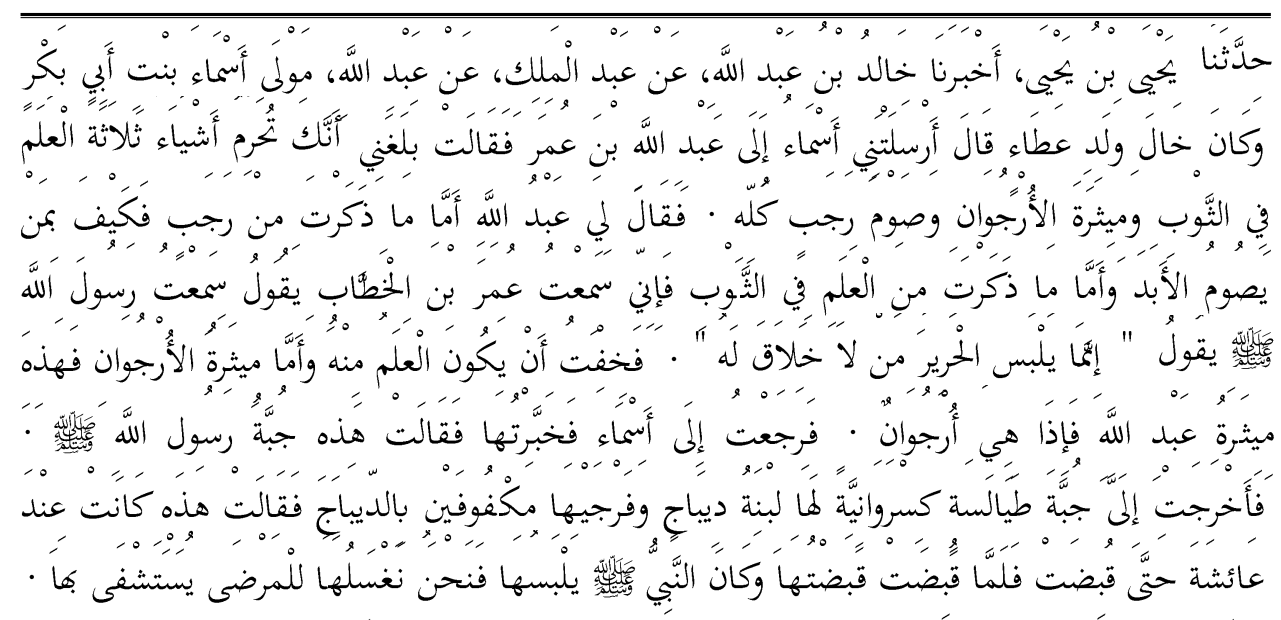

(Sahih Muslim 2069a)

Let us review another similar narration and then we will present our analysis of these.

Hadith 17: Narrated Asma: Abdullah Abu Umar, a client of Asma', daughter of Abu Bakr, said: I saw Ibn Umar buying a Syrian garment in the market. When he saw that it had a red warp, he returned it. I then came to Asma' and mentioned it to her. She said: Bring me, slave-girl, the mantle of the Messenger of Allah (- She brought out a mantle of a course ornamented cloth, with its collar, sleeves, front, and back were hemmed with brocade.

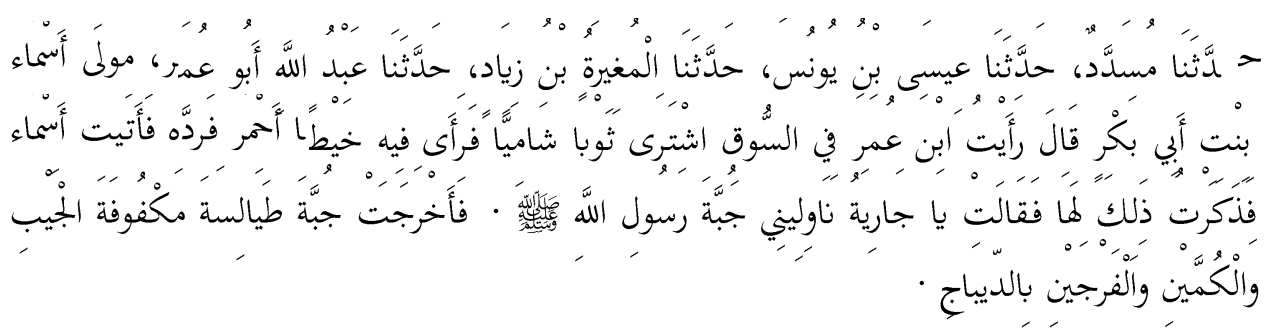

(Sunan Abi Dawud 4054 - Saheeh)

The above two ahadith explain that it was only the women who were 
The Scholar Islamic Academic Research Journal

Vol. 6, No. 2 || July -December 2020 || P. 48-85

https://doi.org/10.29370/siarj/issue11ar3

aware about this dress of the Prophet. Asma R.A. got this dress from the noble wife of the Prophet Ayesha R.A.; As the other companions do not seem to recognize this aspect, it seems to indicate that it was a dress worn in the house. Accordingly, it can be said that there is no impermissibility of such dresses inside one's house. This is consistent with the fatwa of Imam Malik quoted above.

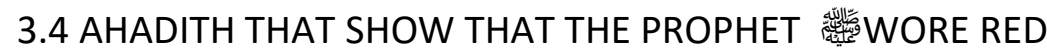

Hadith 18: Abu Juhaifah narrated: "I saw Bilal calling the Adhan, and turning, and his (face) was following here and there, and his (index) fingers were in his ears, and Allah's Messenger was in a small red tent" - "I think," he (one of the narrators) said, "it was made from a hide" - so Bilal went out in front of him with an Anazah which he planted (in the ground) at Batha. Allah's Messenger prayed facing it, and a dog and a donkey passed in front of him (meaning that it does not break the prayer if animate beings pass in front of the anazah while the Imam is praying behind it); he was wearing a red Hullah, and it is as if I am now looking at the radiance of his shins." Sufyan said: "We think that it was a Hibrah."

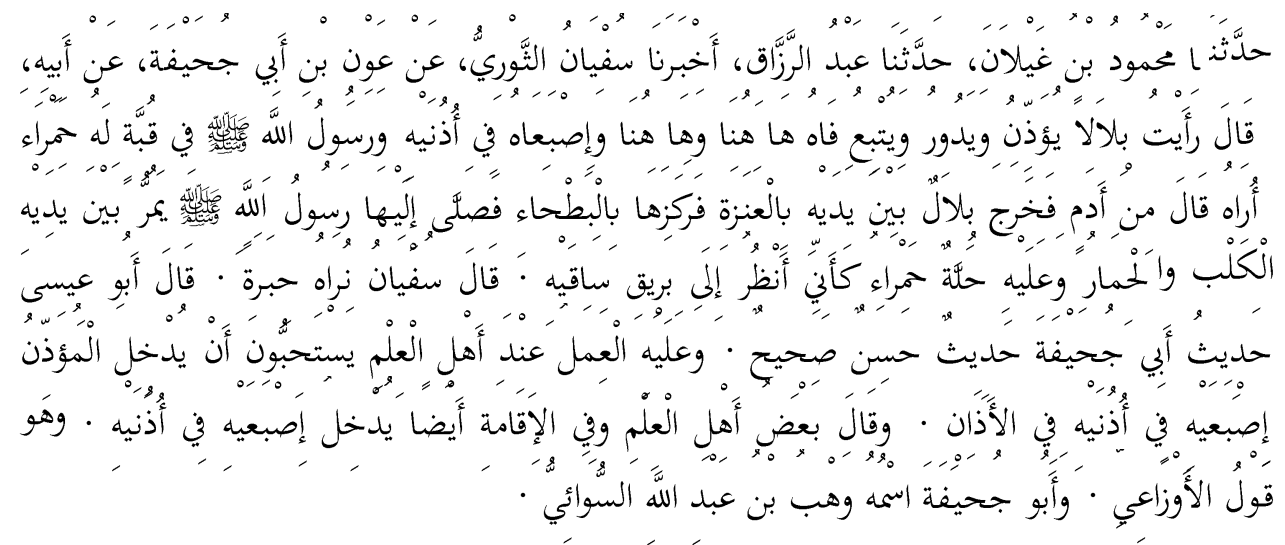

(Jami`at-Tirmidhi 197 - Saheeh) 
The Scholar Islamic Academic Research Journal

Vol. 6, No. 2 || July -December 2020 || P. 48-85

https://doi.org/10.29370/siarj/issue11ar3

Other ahadith that convey the same or similar message:

- Hadith 19: Saheeh Muslim 503A

- Hadith 20: Saheeh Muslim 503B

- Hadith 21: Saheeh Bukhari 376

- Hadith 22: Sunan Abu Dawud 520

- Hadith 23: Sunan Nasai 772

None of the ahadith above mention any specific design of the clothing or if it had any stripes.

Hadith 24: Abu Juhayfah (R.A) says, "I saw Rasulullah wearing a pair of red (colored) clothing. The luster of the feet of Rasulullah is still before me." Sufyaan (R.A) who is a narrator of this hadith says: "According to my understanding the pair (of clothing) was printed red."

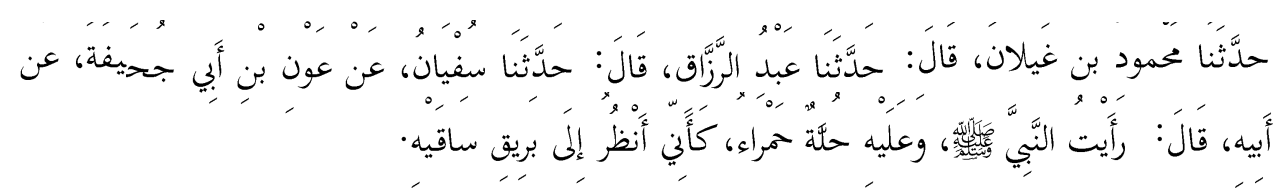

(Ash-Shama'il Al-Muhammadiyah 64 - Saheeh)

Hadith 25: Narrated Jabir Bin Samurah: "I saw the Prophet ( on a clear night, so I looked at the Messenger of Allah (the and at the and he was wearing a red Hullah, and he looked better than the moon to me."

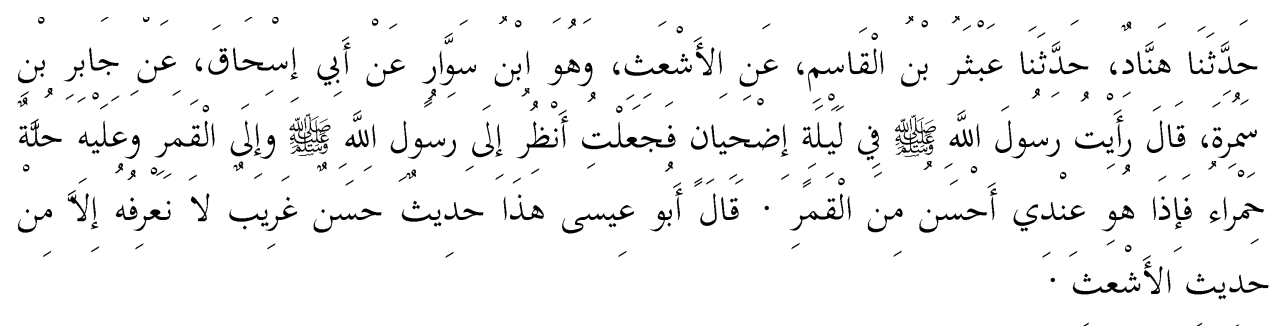

(Jami Tirmidhi - Book 43, Hadith 3041 - Daif) 
Other ahadith that convey the same or similar message:

- Hadith 26: Ash-Shama'il Al-Muhammadiyah 10 - Daif

Hadith 27: Narrated Al-Bara: The Prophet (yas of a modest height (i.e. neither excessively tall nor short). I saw him wearing a red suit, and I did not see anyone better-looking than him.

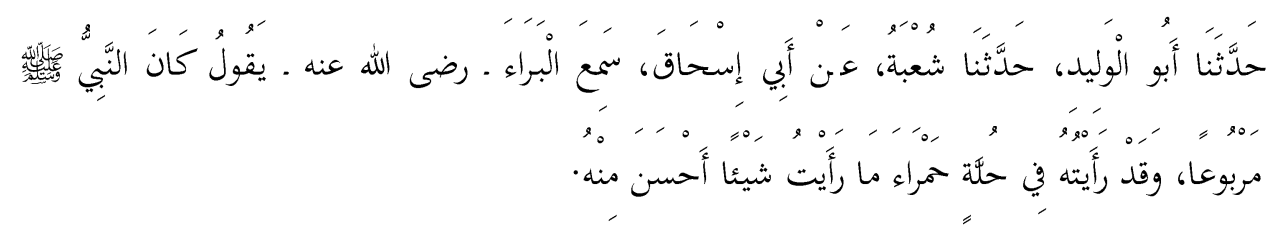

(Sahih al-Bukhari 5848)

Other ahadith that convey the same or similar message:

- Hadith 28: Sunan Ibn Majah Book 32, hadith 3710;

- Hadith 29: Sunan an-Nasa'i 5060

- Hadith 30: Sunan an-Nasa'i 5062

- Hadith 31: Sunan an-Nasa'i 5232

- Hadith 32: Sunan an-Nasa'i 5314

- Hadith 33: Saheeh Bukhari 3551

- Hadith 34: Saheeh Bukhari 5901

- Hadith 35: Jami Tirmidhi Book 49 hadith 3995

- Hadith 36: Jami Tirmidhi 1724

- Hadith 37: Shamail Muhammadiyyah 3

- Hadith 38: Shamail Muhammadiyyah 4

- Hadith 39: Shamail Muhammadiyyah 65

- Hadith 40: Sunan Abu Dawood 4072

- $\quad$ Hadith 41: Sunan Abu Dawood 4183 
- Hadith 42: Saheeh Muslim 2337A

- Hadith 43: Saheeh Muslim 2337B

- Hadith 44: Mussanaf Ibn Abi Shayba 25077

As shown from the above, there are plenty of Saheeh ahadith that explain this event, and all of them mutually support and strengthen each other. None of the versions of the ahadith referenced above explain any specific design of the clothing or if it had any stripes. It is to be noted that some scholars opined that the red dress of the Prophet contained the stripes as per the norm of the time. Based on that, they gave the ruling that if red is mixed with other colors in the design of the cloth, it is acceptable to wear it in that case. However, it is their interpretation of the hadith and not necessarily supported by another group of scholars as we have explained further in section 5 .

Hadith 45: Narrated Amir: I saw the Messenger of Allah (政) at Mina giving a sermon on a mule and wearing a red shawl, while Ali was announcing (in front of him so that people are able to hear the words of the Prophet

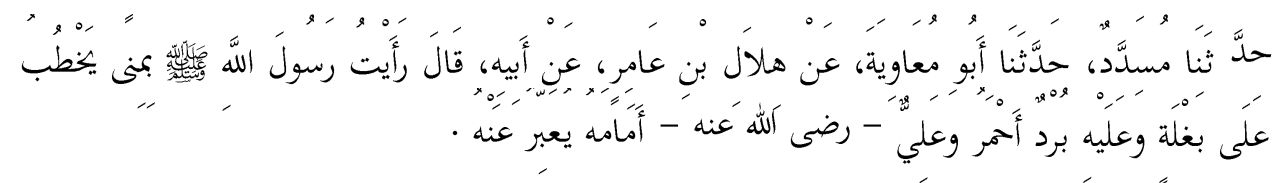

(Sunan Abi Dawud 4073 - Saheeh)

\subsection{BURIAL IN RED SHROUD:}

Hadith 46: Narrated Abdullah ibn Abbas:

The Messenger of Allah (倸) was shrouded in three garments made in 
Najran: two garments and one shirt in which he died.

Abu Dawud said: The narrator 'Uthman said: In three garments: two red garments and a shirt in which he died.

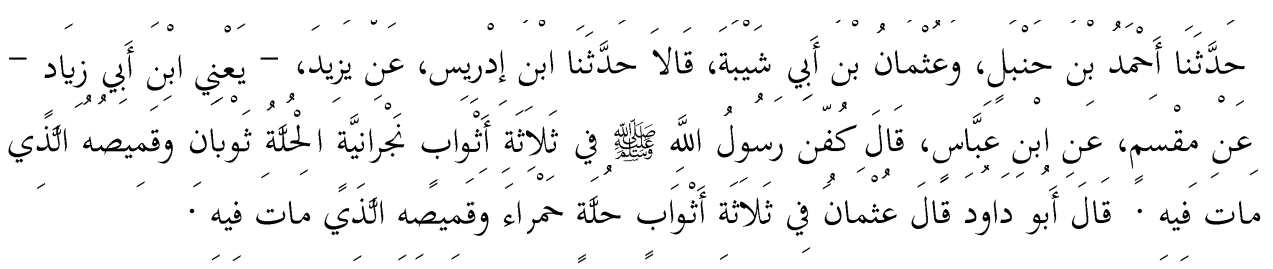

(Sunan Abi Dawud 3153 - Daif)

As the above hadith is Daif, and the information in this is contrary to many Saheeh ahadith which mention the white shroud, it is not to be acted upon. We are accordingly presenting another hadith on this topic from Muwatta Imam Malik.

Hadith 47: Yahya related to me from Malik that Yahya ibn Said said that he had heard that when Abu Bakr as-Siddiq was ill, he asked A'isha, "How many shrouds did the Messenger of Allah, may Allah bless him and grant him peace, have?" and she replied, "Three pure white cotton garments." Abu Bakr said, "Take this garment (a garment he was wearing on which red clay or saffron had fallen) and wash it. Then shroud me in it with two other garments." A'isha said, "Why's that?", and Abu Bakr replied, "The living have greater need of the new than the dead. This is only for the body fluids that come out as the body decays."

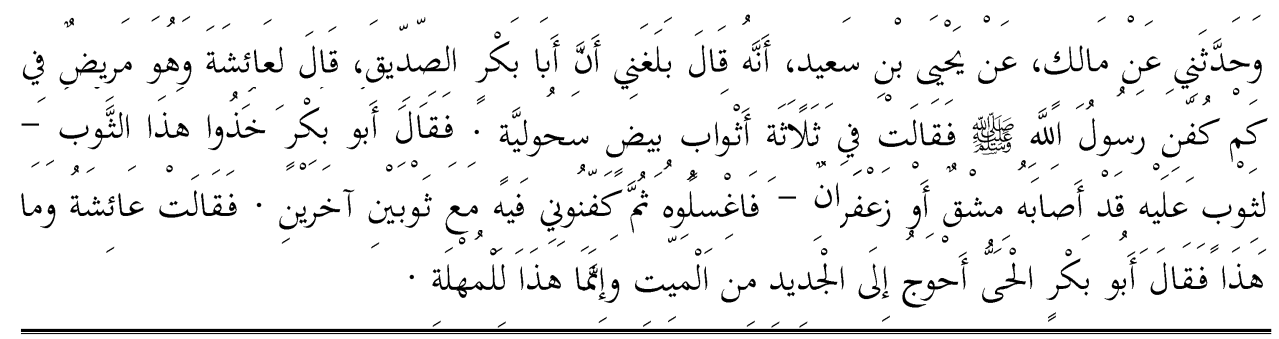


The Scholar Islamic Academic Research Journal

Vol. 6, No. 2 || July -December 2020 || P. 48-85

https://doi.org/10.29370/siarj/issue11ar3

(Muwatta Imam Malik, Book 16, Hadith 528)

\subsection{USE OF RED TENT}

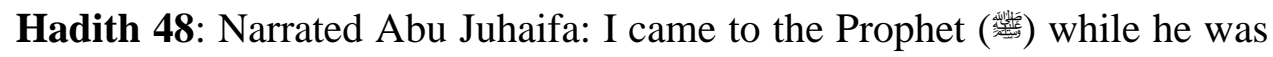
inside a red leather tent, and I saw Bilal taking the remaining water of the ablution of the Prophet, and the people were taking of that water and rubbing it on their faces; and whoever could not get anything of it, would share the moisture of the hand of his companion (and then rub it on his face).

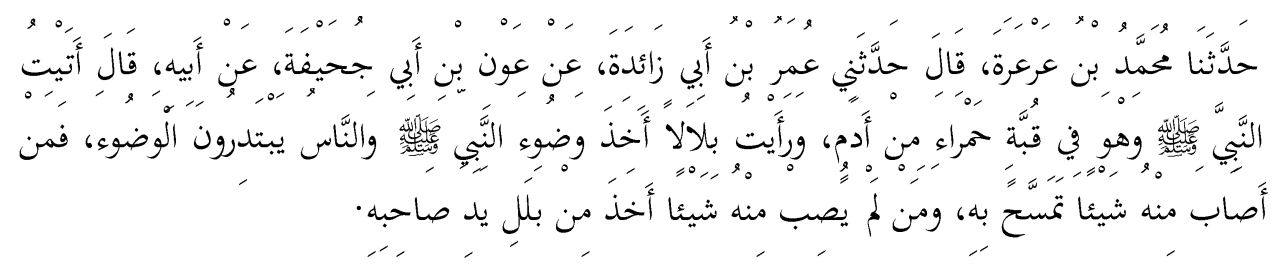

(Sahih al-Bukhari 5859)

Other ahadith that convey the same or similar message::

- Hadith 49: Sunan Ibn Majah 711

- Hadith 50: Sunan an-Nasa'i 5378

\subsection{WEARING RED AND SILK FOR WOMEN:}

Hadith 51: Narrated Umm Salamah, Ummul Mu'minin:

The Prophet (4aid: A woman whose husband has died must not wear clothes dyed with safflower (usfur) or with red ochre (mishq) and ornaments. She must not apply henna and collyrium. 


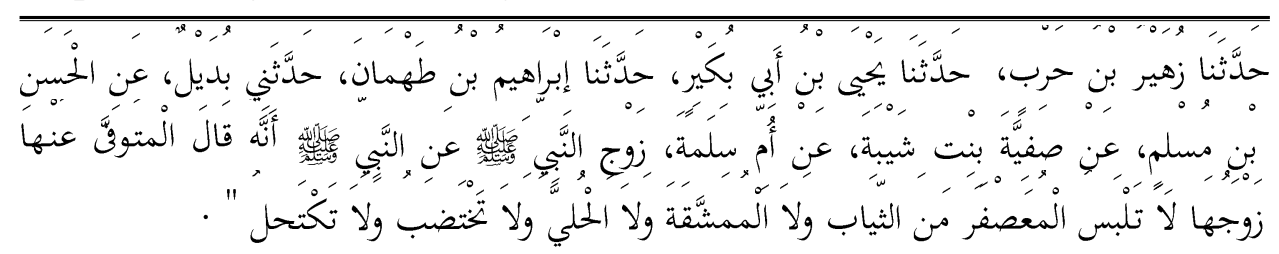

(Sunan Abi Dawud 2304 - Saheeh)

The same or similar point is also mentioned in:

- Hadith 52: Sunan Nasai 3535

The above ahadith indicate that it is generally permissible for women to use the above-mentioned type of dress; however, in the situation of sadness of death, they were prohibited from its use. The general permissibility is also evident from the hadith below.

Hadith 53: Hadith Narrated Anas bin Malik: that he had seen Um Kulthum, the daughter of Allah's Messenger (wilk garment.

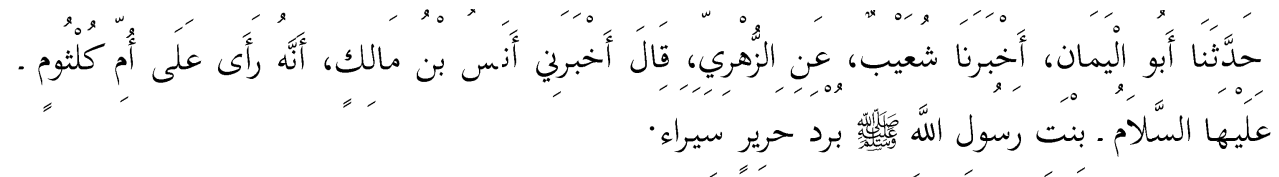

(Sahih al-Bukhari 5842)

Though the above ahadith indicate the permissibility of red dresses for women, the following hadith gives a hint that the Prophet disliked it. However, it is Daif and cannot be used as evidence for deriving the ruling.

Hadith 54: Narrated Hurayth ibn al-Abajj as-Sulayhi:

That a woman of Banu Asad: One day I was with Zaynab, the wife of the Messenger of Allah (were dyeing her clothes with red ochre. In 
the meantime, the Messenger of Allah ( peeped us. When he saw the red ochre, he returned. When Zaynab saw this, she realized that the Messenger of Allah ( disapproved of what she had done. She then took and washed her clothes and concealed all redness. The Messenger of Allah (then returned and peeped, and when he did not see anything, he entered.

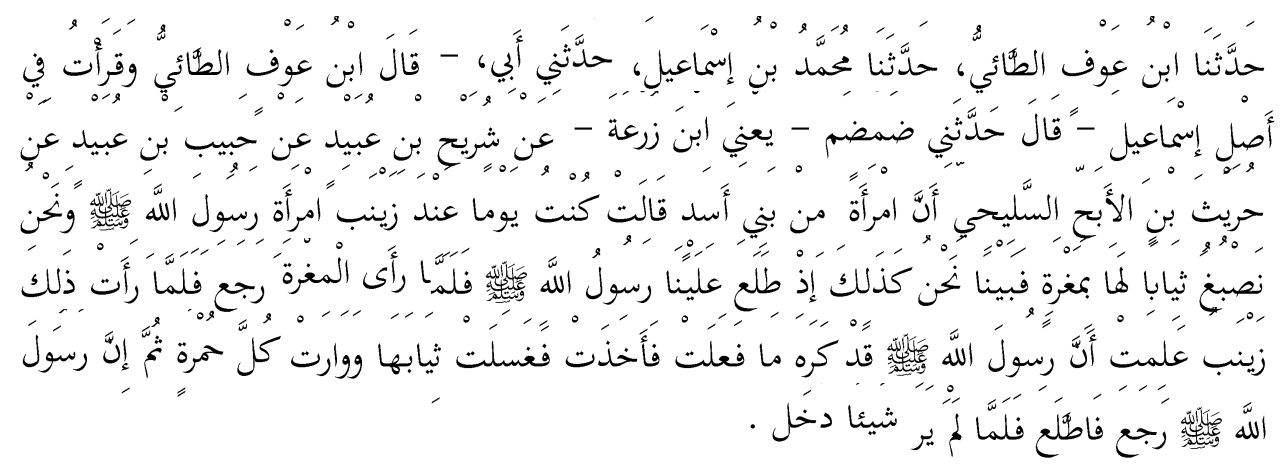

(Sunan Abi Dawud 4071 - Daif)

Ochre or ocher is a natural clay earth pigment that is a mixture of ferric oxide and varying amounts of clay and sand. It ranges in color from yellow to deep orange or brown ${ }^{9}$.

4. Literature review: Ahadith that indicate prohibition to own or wear red clothing or similar material:

\subsection{AHADITH ABOUT PROHIBITION TO USE AL-MAYATHIR:}

In order to understand the context of the prohibition of al-Mayathir and

\footnotetext{
9 "What Is Ochre?," 2010, http://www.personally-selected-aboriginalart.com/ochre.html.
} 
The Scholar Islamic Academic Research Journal

Vol. 6, No. 2 || July -December 2020 || P. 48-85

https://doi.org/10.29370/siarj/issue11ar3

what it means, we have presented a few relevant ahadith below:

Hadith 55: It was narrated that 'Abidah said: "He forbade red AlMayathir, and gold rings."

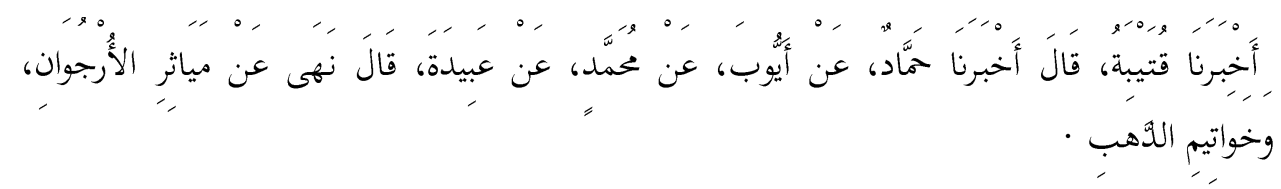

(Sunan an-Nasa'i 5185 - Saheeh)

Over here, it is important to note that in numerous ahadith, the use of gold rings and mayathir has come together, e.g.

- Hadith 56: Saheeh Muslim 2066A,

- Hadith 57: Saheeh Muslim 2978D;

- Hadith 58: Saheeh Bukhari 5175,

- Hadith 59: Saheeh Bukhari 5635,

- Hadith 60: Saheeh Bukhari 5849,

- Hadith 61: Saheeh Bukhari 6235;

- Hadith 62: Sunan Nasai 1939,

- Hadith 63: Sunan Nasai 4254,

- Hadith 64: Sunan Nasai 5150,

- Hadith 65: Sunan Nasai 5165,

- Hadith 66: Sunan Nasai 5166,

- Hadith 67: Sunan Nasai 5184,

- Hadith 68: Sunan Nasai 5309;

- $\quad$ Hadith 69: Musnad Ahmed 831,

- Hadith 70: Musnad Ahmed 981,

- Hadith 71: Musnad Ahmed 1254;

- Hadith 72: Jami Tirmidhi 1760; 
- Hadith 73: Riyad us Saliheen 239;

- Hadith 74: Adab ul Mufrad 924

- Hadith 75: Sunan Abi Dawud 4070

Therefore, it is imperative to review those ahadith together.

- When the translations of the word following is noted:

a. Al-Mayathir is defined in the hadith Sunan an-Nasa'i 5376 (Hadith 76) and Saheeh Muslim 2078D (Hadith 77) as:

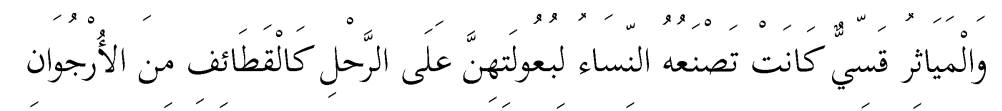

i.e., Al-Maythar is Qassi (a silky substance) which the women used to put on the saddles for their husbands, such as red cushions.

These words seem to be the explanation of the mohadith or the narrator of the hadith.

b. According to Sunan an-Nasa'i 4254 (Hadith 78), the

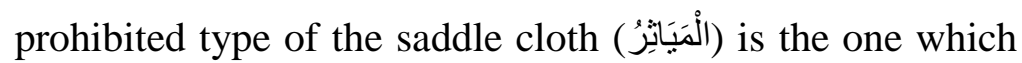
is made from the leopard skin. The wording of the hadith is:

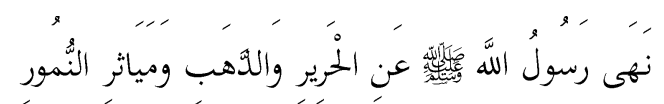

"The Messenger of Allah forbade silk, gold and saddlecloths (Miyathir) made of leopard skin.

The other ahadith which also prohibit riding on either leopard skin or the cushions made from it include:

- Hadith 79: Sunan Ibn Majah, Book 32 Hadith 3786

- Hadith 80: Sunan Ibn Majah, Book 32 Hadith 3787 
- Hadith 81: Sunan Abu Dawud 1794

- Hadith 82: Sunan Nasai 4049

- Hadith 83: Sunan Nasai 5091,

- Hadith 84: Musnad Ahmed 1254.

Two of these ahadith have been graded as Hasan while the others are Daif.

c. iَis also translated as silk cushion filled with cotton or a form of silk carpet put on the saddle

d. The wording in one of the ahadith (which appears to be an explanation of the narrator or the mohadith) mentions:

Hadith 85: It was narrated that 'Ali said:

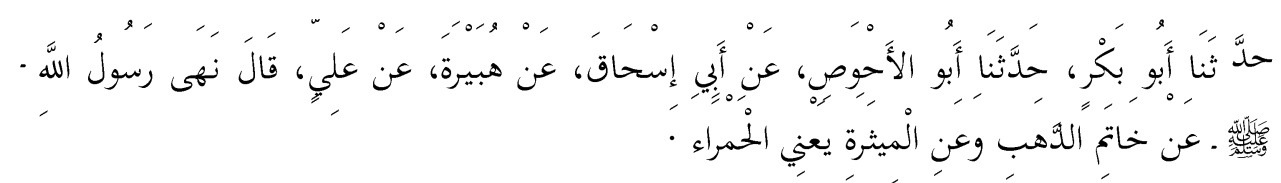

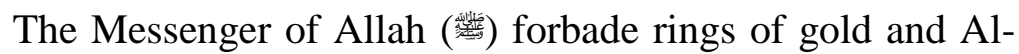
Mitharah (plural of Mayathir) meaning the red ones.

Sunan Ibn Majah, Book 32, Hadith 3785 - Hassan

In this wording, the prohibited type of mayathir is the red one without any further explanation.

If the above is looked at holistically, it can be inferred that the word either indicates a silky [red] saddle cover or cushion, or a saddle cover made with leopard skin.

Explaining the rationale for the ruling, the scholars tell that such saddle- 
The Scholar Islamic Academic Research Journal

Vol. 6, No. 2 || July -December 2020 || P. 48-85

https://doi.org/10.29370/siarj/issue11ar3

covers were pre-dominantly a custom of the non-Muslims ${ }^{10}$ at the time.

This could also have links with the customs of the period of jahiliyyah.

\subsection{AHADITH ON CLOTHING DYED WITH SAFFLOWER}

Hadith 86: Narrated 'Ali (RA): Allah's Messenger (torbade wearing of silk and clothes dyed with safflower (a yellow-red dye). [Reported by Muslim].

Al-Muasfar means: Coloured / dyed with safflower which is yellow in colour.

$$
\begin{aligned}
& \text { وعَن علَِ - رضى الله عنه - }\} \\
& \text { المعصفر: المصبوغ بالعصفر، وهو صبغ أصفر اللون. }
\end{aligned}
$$

(Bulugh ul Maram - Book 2, Hadith 531)

Hadith 87: Narrated 'Abdullah bin 'Amr (RA):

The Prophet (器) saw me in two clothes dyed in safflower (a red dye), whereupon he said: "Did your mother order you to do this?" [Reported by Muslim].

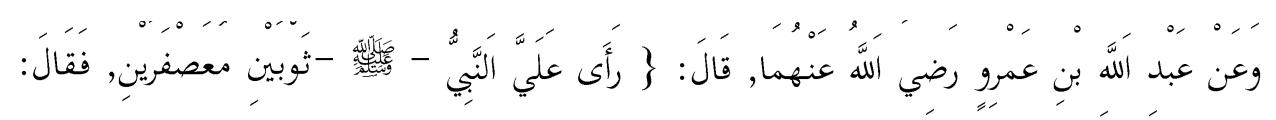

10 "Fatwa No: 18563: Wearing Plain Red Colored Clothes Is Permissible for Men in One Condition Only," IslamWeb, 2015, https://www.islamweb.net/en/fatwa/18563/wearing-plain-red-coloredclothes-is-permissible-for-men-in-one-condition-only. 
(Bulugh ul maram Book 2, Hadith 532)

Hadith 88: It was narrated that Ibn 'Umar said:

“The Messenger of Allah ( forbade Al-Mufaddam."

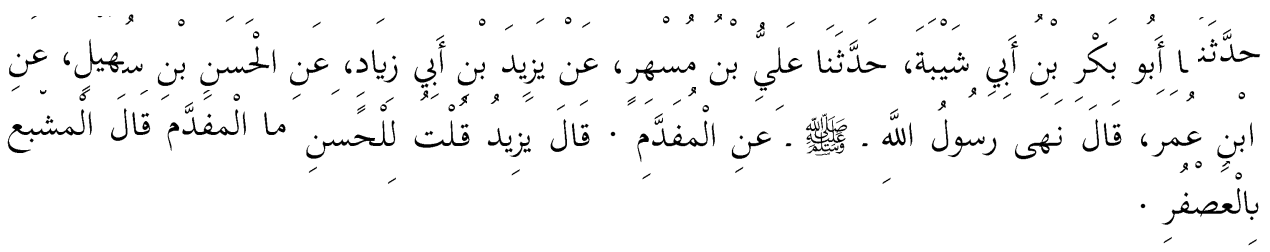

(Sunan Ibn Majah, Book 32, Hadith 3732 - Hassan)

A garment strongly dyed with safflower so as to be dark red.

The above indicates that it was forbidden for men to wear in public any clothing dyed in saffron or safflower.

\subsection{SPECIFIC PROHIBITION OF WEARING RED:}

Hadith 89: Narrated 'Abdullah bin 'Amr:

"A man passed by while wearing two red garments. He gave Salam to the Prophet ( but he did not return the Salam."

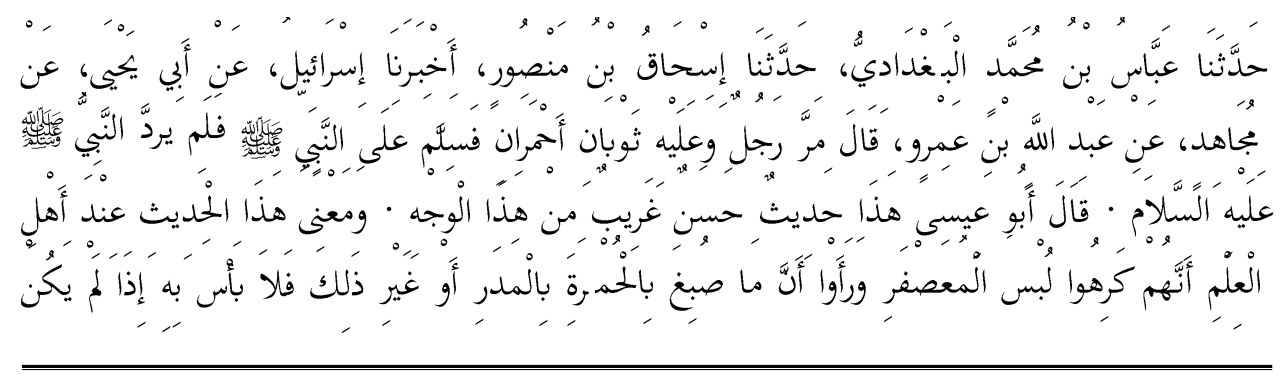


(Jami Tirmidhi - Book 43, Hadith 3037 - Daif)

Though the above hadith is Daif (as classified by Shaykh Albani) and cannot be used as an evidence, in the explanation of this hadith, the scriber has made an explanatory comment which indicates that the people of knowledge considered Al-Muasfar to be makrooh. We have already provided a definition of Al-Muasfar earlier in this paper.

The hadith below also conveys the same meaning and message; however, it is also Daif and cannot be used to derive the ruling.

- Hadith 90: Sunan Abi Dawud 4069

Hadith 91: It was narrated that 'Ali (رضي الله عنه) said:

The Messenger of Allah (orbade me to wear gold rings, to wear red, and to recite Qur`an whilst bowing and prostrating.

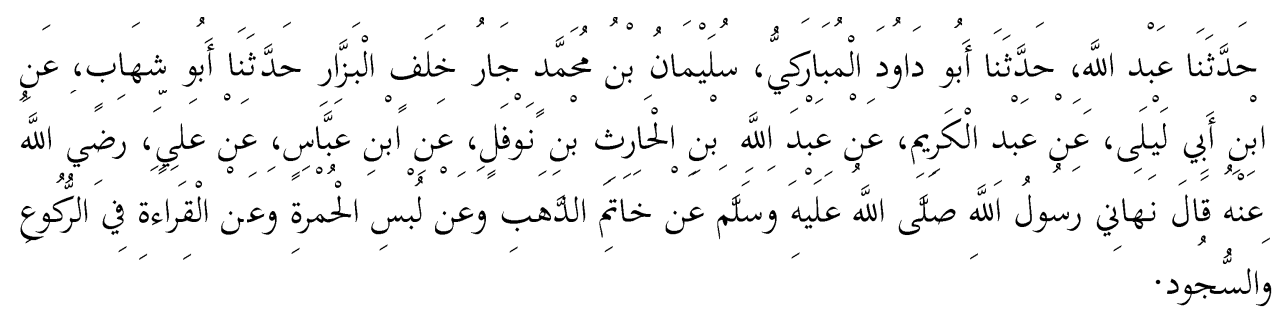

(Musnad Ahmad 829)

The above hadith has weakness in its isnad because of the presence of Muhammad bin Abdur Rahman bin Abu Laila and Abdul-Kareem.

Another narration that conveys the same meaning is as follows and it contains weakness in the chain too: 
- Hadith 92: Musnad Ahmad 939

From other ahadith from Ali R.A. on this topic, which are stronger and reach the level of acceptability, we come to various other possible reasons for prohibition apart from just being red (e.g. some narrations indicate that it was silk or a blend of it which the Prophet forbade).

Hadith 93: It was narrated that 'Ali (رضي الله عنه) said:

The Messenger of Allah (wear forbade me to wear gold rings, to wear garments made from a blend of linen and silk, and to use red saddlecloths.

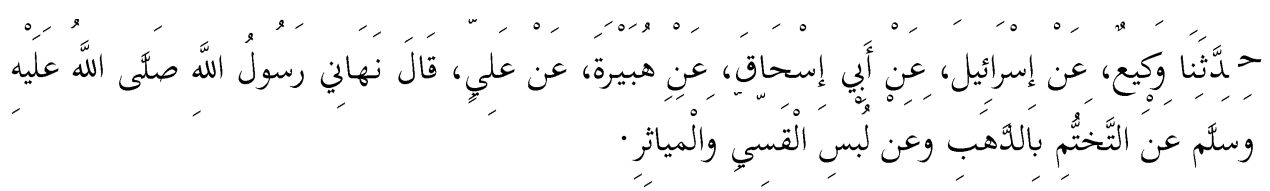

(Musnad Ahmad 1049 - Hassan)

Other ahadith that corroborate with the above include:

- Hadith 94: Musnad Ahmed 1113

- Hadith 95: Musnad Ahmed 1159

- Hadith 96: Sunan an-Nasa'i 1042

- Hadith 97: Sunan an-Nasa'i 5173

- Hadith 98: Sunan an-Nasa'i 1118

- Hadith 99: Sunan an-Nasa'i 5172

- Hadith 100: Musnad Ahmed 601

- Hadith 101: Musnad Ahmed 831

- Hadith 102: Musnad Ahmed 1124

- Hadith 103: Sahih Muslim 2078d

It is to be noted that ruling of the above ahadith is generic and applicable 
to everyone. Though some narrations, for example, the hadith below, indicate that they were specific to Ali R.A. however, that is not considered to be the case. The hadith below is also Daif and cannot be used as evidence.

Hadith 104: It was narrated that Abu Hurairah (رضي الله عنه) said:

‘Uthman (رضي الله عنه) went to Makkah for Hajj (where he saw this event).

The wife of Muhammad bin Ja`ar bin Abi Talib entered upon him (i.e., her husband) and he spent the night with her. Then the next morning, he (i.e., Muhammad bin Ja far) came out smelling of perfume and wearing a wrapper saturated with safflower dye. He caught up with the people in weariness before they set out.

When 'Uthman saw him, he rebuked him and expressed disapproval, saying: Are you wearing something dyed with safflower when the Messenger of Allah ( رضي الله عنه) forbade that? 'Ali bin Abi Talib to him: The Messenger of Allah ( did not forbid it to him or you; he only forbade it to me.

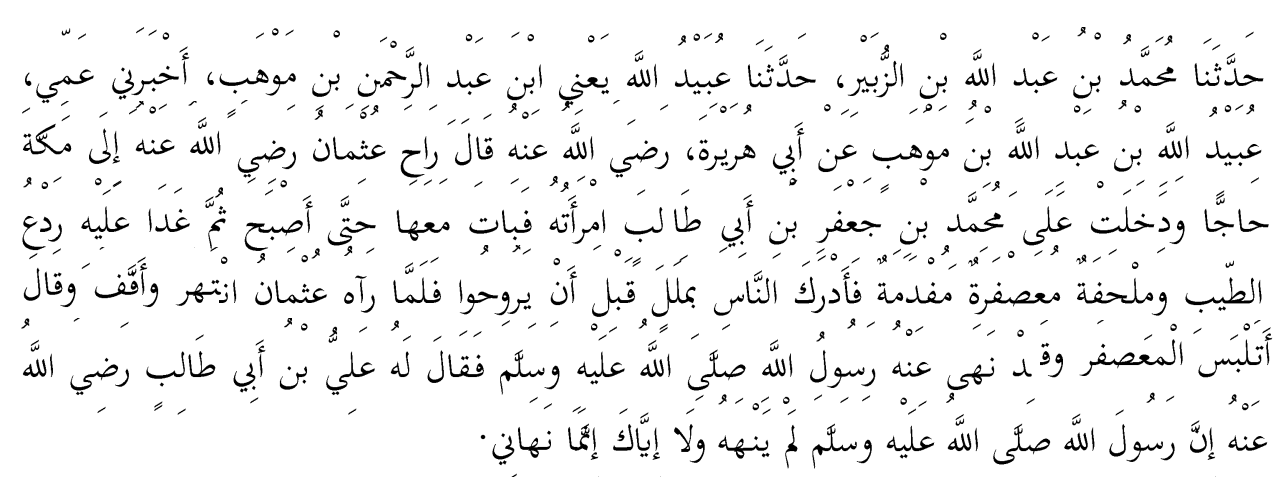

(Musnad Ahmad 517 - Daif) 
The Scholar Islamic Academic Research Journal

Vol. 6, No. 2 || July -December 2020 || P. 48-85

https://doi.org/10.29370/siarj/issue11ar3

5. Analysis:

\subsection{SUMMARY OF THE RELEVANT AHADITH:}

From the above ahadith, we learn the following:

1. It is established that the Prophet owned a red cloth which according to some narrations was his shawl; it was put in his blessed grave.

2. Several ahadith indicate that the Prophet also includes the narrations that he used to wear red clothing on eid.

3. It is established that the companions wore red-colored clothing in various forms e.g. suits, turbans, and so on; they did that in public.

4. It is established that the children among the companions also wore red shirts

5. Narrations indicate the permissibility for men to wear red in their houses

6. Some scholars have opined that the dress of the Prophet purely or entirely red; rather it was a mixture of red with some other color, e.g. designed in the form of alternating stripes of red with some other color ${ }^{11}$. Shaykh Muhammad Ali Ferkus, however, has objected to this understanding. He says regarding the opinion

${ }^{11}$ Mufti Waseem Khan, "Explanation Of The Prohibition Of Wearing Gold And Red Colours For Males" (Darul Uloom Trinidad \& Tobago, 2014), https://darululoomtt.net/explanation-prohibition-wearing-gold-redcolours-males/. 
that "the red cloak is from two Yemeni garments woven with red and black strips" that "this reconciliation lacks proof, as the Sahâbi (who narrated the hadith) is the one who knows perfectly the Arabic language, and he described it as being red, so it should be understood as described (pure red) only, because it is the real meaning of this word, and explaining the speech of the Sahâbi by what it means in the language of his people is sounder and more correct, and we should not interpret figuratively unless there is a proof that makes us do so, as it is established in books dealing with such issues." 12

7. There are some narrations about the shroud of the Prophet red but they have not reached the level of acceptability according to the mohaditheen

8. Use of red color in general use substances and objects (e.g tents) is also permitted.

9. Women are permitted to wear red except in the case of the death of their husbands. This indicates that the color or material used to dye the cloth red does not go with the event of sadness and has some connotation of happiness or warmth linked to it.

10. Several ahadith prohibit the use of a particular type of red saddle.

11. Several ahadith prohibit men to wear clothing dyed with safflower or saffron.

12. The ahadith dealing with the prohibition of wearing red in general

${ }^{12}$ M. A. Ferkus, "The Ruling Concerning Praying in a Red Garment," The official website of Sheikh Muhammad Ali FERKUS, 2020, https://ferkous.com/home/?q=en/fatwa-en-2. 
The Scholar Islamic Academic Research Journal

Vol. 6, No. 2 || July -December 2020 || P. 48-85

https://doi.org/10.29370/siarj/issue11ar3

are either weak $^{13}$ or are about silk or some other prohibited categories of clothing rather than any red clothing in general.

\subsection{FACTORS TO CONSIDER WHEN DERIVING THE RULING}

5.2.1 Islam is a religion of convenience as we learn from the hadith below:

Narrated Anas bin Malik: The Prophet (4aid, "Make things easy for the people, and do not make it difficult for them, and make them calm (with glad tidings) and do not repulse (them).

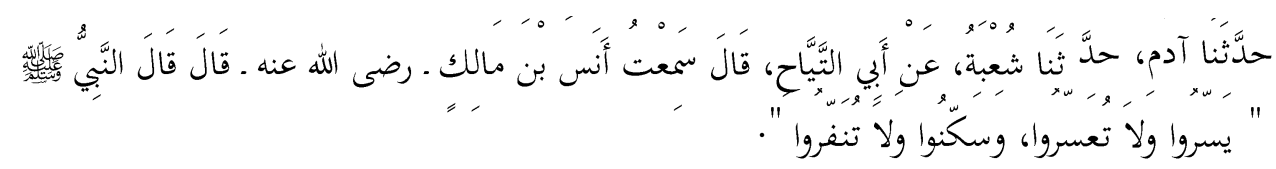

(Sahih al-Bukhari 6125)

Therefore, when Islam restricts something, it does not do so without any valid underlying reason. In the case of clothing also, we need to identify what possible reasons and factors we will need to consider while deriving the ruling.

5.2.2 One of the principles in this regard is that Islam commands to maintain a separate identity for men and women and any efforts to blur this are prohibited. It is to promote modesty and chastity in society and avoid any behaviors that may become a hurdle to a peaceful married life. This principle becomes clear from the hadith below:

\footnotetext{
${ }^{13}$ Khalid Saifullah Rahmani, "Preferred and Disapproved Colors for Clothing."
} 
Narrated Ibn 'Abbas: "The Messenger of Allah (类) cursed the women who imitate men and the men who imitate women."

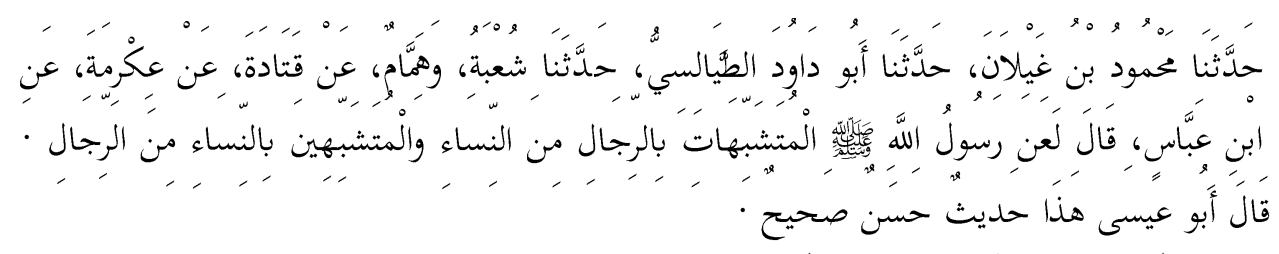

(Jami Tirmidhi, Book 43, Hadith 3013 - Saheeh)

5.2.3 Muslims are discouraged from imitating the non-believers. We learn this from the hadith below and other narrations on the topic:

Ibn Umar reported: The Messenger of Allah, peace, and blessings be upon him, said, "Whoever imitates a people is one of them."

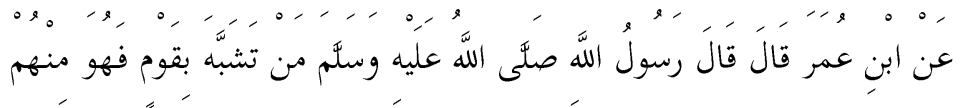

(Sunan Abu Dawud 4031 - Saheeh)

However, it is to be noted that scholars explain that this imitation is about their religious customs. In this context, we can say that if a Muslim starts wearing red pilgrimage clothing like the Buddhist monks or the pilgrimage clothing of the Hindus that would certainly be an act not in alignment with the relevant directives from the Quran and Sunnah. However, if the conditions for tashabuh (imitartion) set by the fuqaha in accordance with the Quran and Sunnah are not met, it is not considered to be a blameworthy form of tashabuh. For example, if Muslims travel in cars just like non-Muslims do, there is nothing wrong with this similarity or imitation of a traveling procedure. Scholars have extensively written on this subject to clarify the common misconceptions surrounding the matter 
The Scholar Islamic Academic Research Journal

Vol. 6, No. 2 || July -December 2020 || P. 48-85

https://doi.org/10.29370/siarj/issue11ar3

of imitation of non-believers. ${ }^{14}$

\subsection{RULINGS BY SCHOLARS:}

Considering the ahadith mentioned in the literature review section and other evidence, the scholars have adopted various approaches to deriving the ruling. Some of the possible reasons behind their fatawa are listed below:

- Some scholars have given tarjeeh or preference to some ahadith over others (e.g. based their ruling on the ahadith mentioned in section 4 while giving them preference over the ahadith mentioned in section 3)

- Some scholars have considered the prohibition to wear red to be generic; however, they gave it the status of 'being disliked' (makrooh) as opposed to haram as the Prophet and his companions wore it and hence setting the criteria that the prohibition by the prophet to wear red was in the sense of something being disliked rather than being haram

- Some scholars have explained that the prohibition was for pure red clothing (except for a few items, e.g. turban) and the dress of the Prophet was not pure red. They accordingly allowed without any dislikeness the wearing of a dress in which red is mixed with some

${ }^{14}$ Subaib Webb, "A Working Explanation on the Hadith of 'Imitation' Suhaib Webb | Virtual Mosque" (Virtual mosque, 2008), https://www.virtualmosque.com/islam-studies/a-working-explanation-onthe-hadith-of-imitation-suhaib-webb/. 
other cloth but prohibited wearing pure red ${ }^{15}$.

- Some scholars have allowed wearing red as the ahadith that deal with its prohibition are weaker than the ones that show its permissibility $^{16}$

- Some scholars have prohibited the red clothing dyed in saffron or safflower and allowed the rest.

- Another possibility of giving a fatwa for the permissibility or impermissibility of wearing red could have been the impact of naskh or abrogation. But no such evidence could be found in the writings of the scholars surveyed for this paper.

Accordingly, seven ${ }^{17}$ or eight ${ }^{18}$ different rulings can be found regarding this matter falling on the contour between "unrestrictedly permissible" to "absolutely forbidden"19. Let us review some of the key opinions.

The opinions below have been summarized by Maulana Khalid Saifullah

15 Ustada Shazia Ahmed, "What Is the Ruling on Men Wearing Red?" (IslamQA, September 14, 2012), https://islamqa.org/shafii/qiblashafii/33169.

${ }^{16}$ M. A. Ferkus, "The Ruling Concerning Praying in a Red Garment."

17 "Fatwa No: 18563: Wearing Plain Red Colored Clothes Is Permissible for Men in One Condition Only."

${ }^{18}$ Khalid Saifullah Rahmani, "Preferred and Disapproved Colors for Clothing."

19 "Fatwa No: 18563: Wearing Plain Red Colored Clothes Is Permissible for Men in One Condition Only." 
The Scholar Islamic Academic Research Journal

Vol. 6, No. 2 || July -December 2020 || P. 48-85

https://doi.org/10.29370/siarj/issue11ar3

Rahmani in his article dealing with the fiqh of clothing: ${ }^{20}$

- The scholars of the Maliki, Shafi'i and other general schools consider it permissible to wear red ${ }^{21}$ (Tuhfat al-Ahwadhi).

- The scholars of the Hanafi school have differed regarding this matter. Some state that wearing red is disliked (tanziha) ${ }^{22}$ while by others it is prohibitively disliked (tahrima).

- Imam Abu Hanifah considered its use as mubah (allowed).

- As per the verdict of Imam Ibn Nujaym, it is disliked for men when the intent is imitation or resemblance of women, disbelievers, or royal arrogance. ${ }^{23}$

- Imam Tabari ${ }^{24}$ and Imam Ibn Hajr explain that wearing of clothing in every color is permissible except that when the garment is completely red, especially the predominantly red outerwear. They

${ }^{20}$ Khalid Saifullah Rahmani, "Preferred and Disapproved Colors for Clothing."

${ }^{21}$ M. A. Ferkus, "The Ruling Concerning Praying in a Red Garment"; Aḥmad ibn 'Alī Ibn Hajar al-' Asqalānī, Fath ul Bari (Lebanon: Dar AlKotob Al-Ilmiyah (DKI), 2011).

${ }^{22}$ Mufti Faisal Riza, "Red Clothes for Men" (Dar ul Ifta Australia, 2020), http://www.fatwa.org.au/red-clothes-for-men.html.

23 "Ala" Al-Din Muhammad Ibn 'Ali Ibn Muhamm Haskafi, Al-durr almukhtar sharh tanwir al-absar (Turath For Solutions, 2013).

${ }^{24}$ Nazri, MKNZ; Khair, NSB; Yusoff, ABM; Razzak, MMA; Nazri, NJZ, "Colour From The Perspective Of Hadith: An Overview" (Icolass 2014 Usm-Poto International Conference On Liberal Arts \& Social Sciences, Vietnam: E D P Sciences, 2015), https://doi.org/10.1051/shsconf/20151804005. 
mention about the urf (or common custom ${ }^{25}$ ) of their time that: "this is not the clothing of honorable people in our times. It is always important to consider ${ }^{26}$ the practices of the honorable people of every era, as long as there is no sin"

- According to Nayl Al-Awtar"27, the colors that the Prophet صلى الله prohibited the men from are dark red dyed clothing (muasfar), saffron color, and dark yellowish-orange. The majority of jurists are of the opinion that these colors are prohibited for men (al-Durr on Hamish).

- It has been related that Imam Shafi'i prohibited the saffron color for men but permitted dark red dyed color. Imam Nawawi, elaborating on this, writes [that] the reason for this verdict of Imam Sha'fi' $i$ is that the narrations regarding the dark red dyed clothing had not reached him. Had they reached him, he would have definitely prohibited them (Sharh al-Muhadhdhab).

Some of the other opinions are as follows:

- The fatwa from Shaykh Ibn Baaz on this matter prohibits wearing red if it with the intention to imitate women or kuffar or if it is the clothing dyed from the prohibited substances; other than that, there

\footnotetext{
${ }^{25}$ John L. Esposito, “Urf” (Oxford Islamic Studies Online, 2020), http://www.oxfordislamicstudies.com/article/opr/t125/e2438.

${ }^{26}$ al-` Asqalānī, Fathul Bari.

${ }^{27}$ Muḥammad ibn 'Alī Shawkānī, Nayl al-awtar min ahadith Sayyid alakhbar: sharh Muntaqa al-akhbar (Dar al-Fann, 1973).
} 
The Scholar Islamic Academic Research Journal

Vol. 6, No. 2 || July -December 2020 || P. 48-85

https://doi.org/10.29370/siarj/issue11ar3

is no problem in wearing the red color ${ }^{28}$.

- According to another fatwa, it is disliked for men to wear clothes with an intense red color unlike those whose red color is light. ${ }^{29}$

- According to some present-day Hanafi scholars, "it is makrooh tahreemi (i.e. impermissible and sinful) for men to wear garments that have been dyed with safflower (red color) or saffron (yellow/orange color). It is permissible for men to wear clothes that have been dyed with anything other than saffron and safflower regardless of the color of the garment. If, however, the garment is plain red and has been dyed with anything other than safflower, then there is a difference of opinion among the Jurists regarding its permissibility for men. The preferred view is that it is makrooh tanzeehi (i.e. disliked and better to avoid, though not impermissible). ${ }^{30}$

- Wearing a red cap or a red turban on the head, however, is permissible without any karaaha (reprehensibility or dislike)

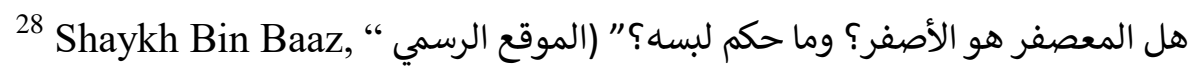
, لسماحة الشيخ الامام ابن باز, 2020) https://binbaz.org.sa/fatwas/22148/\%D9\%87\%D9\%84-

\%D8\%A7\%D9\%84\%D9\%85\%D8\%B9\%D8\%B5\%D9\%81\%D8\%B1$\% \mathrm{D} 9 \% 87 \% \mathrm{D} 9 \% 88-$

\%D8\%A7\%D9\%84\%D8\%A7\%D8\%B5\%D9\%81\%D8\%B1$\% \mathrm{D} 9 \% 88 \% \mathrm{D} 9 \% 85 \% \mathrm{D} 8 \% \mathrm{~A} 7-\% \mathrm{D} 8 \% \mathrm{AD} \% \mathrm{D} 9 \% 83 \% \mathrm{D} 9 \% 85-$ $\% \mathrm{D} 9 \% 84 \% \mathrm{D} 8 \% \mathrm{~A} 8 \% \mathrm{D} 8 \% \mathrm{~B} 3 \% \mathrm{D} 9 \% 87$.
}

29 "Fatwa No: 18563: Wearing Plain Red Colored Clothes Is Permissible for Men in One Condition Only."

${ }^{30}$ Mufti Faisal Riza, "Red Clothes for Men.” 
according to all the Jurists." $" 31$

- Another opinion suggests that it is disliked for men to wear red colored clothes in general if it is with the purpose of adornment and gaining fame, yet that it is permissible for them to wear such color at homes or workplaces. ${ }^{32}$

\section{Conclusion:}

In our opinion, the view of Imam Ibn Hajr Asqalani appears to be the closest representation of the ahadith on this matter. It is mentioned in Fath ul Bari from the Imam:

"The correct and chosen opinion, in our view, is that if the rationale behind the prohibition of wearing red colored clothes [by men] is that it is specific to the disbelievers. Hence, its ruling is like that on using the red Mithyarah [saddle-cloths of non-Arabs made of Deebaj and silk]. This means that it is impermissible for men to wear red colored clothes similar to those of the disbelievers as long as these clothes are specific to them [i.e. non-believers]. If the rationale behind the prohibition of wearing red colored clothes is that they are worn by women, it is because it is forbidden for men to imitate women. In this case, the prohibition is not concerned with the color red in itself but is because of imitating women. If the reason behind the prohibition of wearing red colored clothes by men is it being a means of gaining fame and admiration or undermining manhood,

\footnotetext{
${ }^{31}$ Mufti Faisal Riza.

32 "Fatwa No: 18563: Wearing Plain Red Colored Clothes Is Permissible for Men in One Condition Only."
} 
it is forbidden to wear such clothes whenever these reasons occur; otherwise, the opinion of Imam Malik (may Allah have mercy upon him) is more appropriate here. Malik's opinion suggests that the ruling on wearing plain red clothes at homes is not the same as on wearing them outdoors in gathering places [like the mosque, markets, or the like]"33 From the research undertaken in this paper, we further experienced the correctness of the position that the individual ahadith are like data-points. In order to derive the rulings, all the data-points have to be looked at holistically as many of them explain each other and partial details in some of them are completed by more elaborate explanations available in others. Through this academic exercise and research, we gained valuable experience in reviewing the hadith literature to identify what is generic and what is specific and what is bound and what is open concerning the matters of fiqh. The proper understanding of fiqh cannot be attained without a holistic understanding of the Quran and hadith literature. The approach for holistic analysis adopted in this paper can be utilized in future research work too to derive the fiqhi rulings on the matters under consideration.

\section{(1)(®)}

BY NC SA This work is licensed under a Creative Commons

Attribution-NonCommercial-ShareAlike 4.0 International (CC BY-NC-SA 4.0)

33 al-‘ Asqalān̄̄, Fathul Bari; "Fatwa No: 18563: Wearing Plain Red Colored Clothes Is Permissible for Men in One Condition Only." 